\title{
Development and Validation of an UV-Derivative Spectrophotometric Method for Determination of Glimepiride in Tablets
}

\author{
Rudy Bonfilio, ${ }^{* a}$ Magali B. de Araújo ${ }^{b}$ and Hérida R. N. Salgado ${ }^{a}$ \\ ${ }^{a}$ Departamento de Fármacos e Medicamentos, Faculdade de Ciências Farmacêuticas, \\ Universidade Estadual Paulista, Rodovia Araraquara-Jaú, km 1, 14801-902 Araraquara-SP, Brazil \\ ${ }^{b}$ Departamento de Farmácia, Universidade Federal de Alfenas, Rua Gabriel Monteiro da Silva, 700, \\ 37130-000 Alfenas-MG, Brazil
}

\begin{abstract}
A glimepirida é um fármaco antidiabético oral usado no tratamento da diabetes tipo 2. Este trabalho propôs o desenvolvimento e validação de um método por espectrofotometria derivada na região do ultravioleta para determinação de glimepirida em comprimidos. A quantificação de glimepirida em solução de $\mathrm{NaOH} 5 \times 10^{-3} \mathrm{~mol} \mathrm{~L}^{-1}$ foi realizada usando um intervalo de $8 \mathrm{~nm}$ entre 220 a $300 \mathrm{~nm}$. Os valores de amplitude do espectro de segunda derivada foram obtidos através de unidades de altura de pico entre a linha de base e os sinais em 279,0, 257,5 e 256,3 nm, para quantificação dos produtos Amaryl ${ }^{\circledR} 1 \mathrm{mg}$, Amaryl ${ }^{\circledR} 2 \mathrm{mg}$ e Amaryl ${ }^{\circledR} 4 \mathrm{mg}$, respectivamente. O método foi completamente validado de acordo com o International Conference on Harmonization (ICH) e demonstrou exatidão, precisão, seletividade, robustez e linearidade. O método validado mostrou-se adequado para aplicações em laboratórios de controle de qualidade, pois não utiliza reagentes poluentes, é de simples execução e possui baixo custo.
\end{abstract}

Glimepiride is an oral antidiabetic drug widely used in treatment of type 2 diabetes. This work proposed the development and validation of a derivative UV spectrophotometric method for determination of glimepiride in tablets. The quantification of glimepiride in $5 \times 10^{-3} \mathrm{~mol} \mathrm{~L}^{-1} \mathrm{NaOH}$ was performed by using a wavelength interval of $8 \mathrm{~nm}$ in the range of 220-300 $\mathrm{nm}$. The amplitude values obtained in the second-derivative spectra were arbitrary units of the peak height from the central zero base line to the signals obtained at 279.0, 257.5 and $256.3 \mathrm{~nm}$ for quantification of Amaryl ${ }^{\circledR}$ tablets $1 \mathrm{mg}$, Amaryl ${ }^{\circledR}$ tablets $2 \mathrm{mg}$ and Amaryl ${ }^{\circledR}$ tablets $4 \mathrm{mg}$, respectively. The method was completely validated according to the International Conference on Harmonization (ICH) guidelines, showing accuracy, precision, selectivity, robustness and linearity. The validated method is suitable for quality control applications, since it does not use polluting reagents, it is simple and has low-cost.

Keywords: glimepiride, validation of pharmaceutical methods, derivative-UV spectrophotometry, pharmaceutical quality control

\section{Introduction}

Glimepiride, chemically described as 1-[[4-[2-(3-ethyl4-methyl-2-oxo-3-pyrroline-1-carboxamide) ethyl] phenyl]sulphonyl]-3-(trans-4-methylcyclohexyil) urea, ${ }^{1}$ is a new oral antidiabetic drug from the sulfonylurea class, which is widely used in the treatment of type 2 diabetes. ${ }^{2}$ Glimepiride achieved metabolic control with the lowest dose (1-8 mg daily) of all the sulphonylureas and it maintains a more physiological regulation of insulin

*e-mail: rudybonfilio@yahoo.com.br secretion than glibenclamide, during physical exercise. ${ }^{3}$ It is a white to yellowish-white, crystalline, odorless solid and its molecular formula is $\mathrm{C}_{24} \mathrm{H}_{34} \mathrm{~N}_{4} \mathrm{O}_{5} \mathrm{~S}$. Glimepiride has a molecular weight of $490.62 \mathrm{~g} \mathrm{~mol}^{-1}$ and it is practically insoluble in water. ${ }^{4}$ The chemical structure of glimepiride is shown in Figure 1.

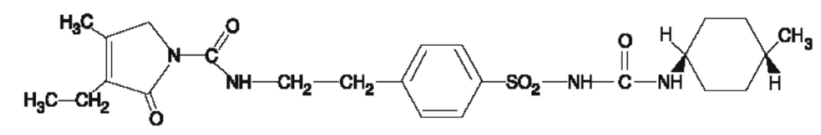

Figure 1. Chemical structure of glimepiride (CAS 93479-97-1). 
The literature described different methods for quantitative determination of glimepiride in human plasma and biological samples. These include high performance liquid chromatography (HPLC) with UV spectrophotometric detection, ${ }^{5}$ semi-microbore high performance liquid chromatography with columnswitching, ${ }^{6}$ micellar electrokinetic chromatography (MEKC), ${ }^{7}$ liquid chromatography/atmospheric pressure chemical ionization mass spectrometry (LC APCI MS $)^{8}$ and liquid chromatography combined with electrospray ionization tandem mass spectrometry (LC ESI MS MS). ${ }^{9-13}$

In pharmaceutical preparations, multiple analytical procedures have been reported for the analysis of glimepiride when it is used as a single active principle or in combined dosage forms, using HPLC with UV spectrophotometric detection, ${ }^{14-20}$ liquid chromatography photo-diode array detection (LC PDA), ${ }^{21}$ liquid chromatography mass spectroscopy (LC MS) ${ }^{21}$ polarography, ${ }^{22}$ high performance thin layer chromatography (HPTLC) ${ }^{23}$ and spectrophotometry. ${ }^{19,24}$ However, HPLC techniques for routine analysis are often time consuming and expensive. Moreover, the described spectrophotometric methods for determination of glimepiride require the use of toxic solvents as methanol ${ }^{19}$ and dimethylformamide. ${ }^{24}$

As an alternative to the existing methods, the aim of this study was to develop, validate and apply an inexpensive, useful and simple derivative UV spectrophotometric method for quantitative determination of glimepiride in commercial pharmaceutical tablet preparations.

\section{Experimental}

\section{Equipments}

The equipments used were the following: Shimadzu ${ }^{\circledR}$ UV-1601 (Kyoto, Japan) recording double beam UVvisible spectrophotometer connected to a computer loaded with Shimadzu UVPC version 3.9 software; ultrasonic bath model USC2800A (Unique ${ }^{\circledR}$, São Paulo, Brazil); analytical balance model 410 (Kern ${ }^{\circledR}$, Kern, Germany); pHmeter PA 200 (Marconi $^{\circledR}$, Piracicaba, Brazil); water distiller system model 425 (Nova Técnica ${ }^{\circledR}$, Piracicaba, Brazil) and quantitative filter paper $\left(\operatorname{Vetec}^{\circledR}\right.$, Rio de Janeiro, Brazil). Chromatographic separations were carried out using a Waters Alliance ${ }^{\circledR} 2690$ liquid chromatograph (Milford, USA) equipped with a Waters ${ }^{\circledR}$ high pressure 1525 pump binary grade, Waters ${ }^{\circledR} 2487$ UV detector and $7725 \mathrm{i}$ manual injector with a $20 \mu \mathrm{L}$ loop. The separation was performed on a Waters Symmetry ${ }^{\circledR}$ C-18 column $(4.6 \mathrm{~mm} \times 250 \mathrm{~mm}, 5.0 \mu \mathrm{m})$.

\section{Chemicals and reagents}

Sodium hydroxide analytical grade was purchased from IMPEX ${ }^{\circledR}$ (Diadema, Brazil) and Dinâmica ${ }^{\circledR}$ (São Paulo, Brazil). Sodium dihydrogenphosphate $\left(\mathrm{NaH}_{2} \mathrm{PO}_{4}\right)$ was used from Reagen ${ }^{\circledast}$ (Colombo, Brazil) and sodium acetate trihydrate was obtained from Synth ${ }^{\circledast}$ (Diadema, Brazil). Methanol was of HPLC grade and acquired from Sigma-Aldrich $^{\circledast}$ (St. Louis, USA). Glimepiride reference substance (assigned purity 100.12\%) was supplied by Zhejiang Xianju Huakang Pharmaceutical \& Chemical Co., Ltd. (Xianju, China). Glimepiride tablets (Amaryl ${ }^{\circledR}$, Sanofi Aventis Us) claimed to contain 1, 2 and $4 \mathrm{mg}$ of the active component were purchased locally. The placebo mixtures were prepared in the laboratory by mixing appropriate amounts (commonly used in tablets) of following pharmaceutical grade excipients: lactose hydrous, sodium starch glycolate, povidone, microcrystalline cellulose, and magnesium stearate. In addition, red ferric oxide was used in the placebo of Amary ${ }^{\circledR} 1 \mathrm{mg}$, yellow ferric oxide and lake indigo carmine in the placebo of Amary $1^{\circledR} 2 \mathrm{mg}$ and lake indigo carmine in the placebo of Amary ${ }^{\circledR} 4 \mathrm{mg}$. The qualitative composition of each placebo was the same as claimed in Amaryl ${ }^{\circledR}$ tablets $1 \mathrm{mg}$, Amaryl ${ }^{\oplus}$ tablets $2 \mathrm{mg}$ and Amary ${ }^{\circledR}$ tablets 4 mg.

\section{Spectrophotometric measurements}

UV-Vis spectra of reference and sample solutions were recorded in $1 \mathrm{~cm}$ quartz cells at a fast scan speed with a fixed slit to lead to a spectral resolution of $2 \mathrm{~nm}$. The second-derivative spectra were obtained by instrumental electronic differentiation (UVPC version 3.9 software) using a wavelength interval $(\Delta \lambda)$ of $8 \mathrm{~nm}$ in the range of 220-300 $\mathrm{nm}$. The amplitude values obtained in the secondderivative spectra were arbitrary units of the peak height from the central zero base line to the signals obtained at 279.0, 257.5 and $256.3 \mathrm{~nm}$ for quantification of Amaryl ${ }^{\circledR}$ tablets $1 \mathrm{mg}$, Amary ${ }^{\circledR}$ tablets $2 \mathrm{mg}$ and Amaryl ${ }^{\circledR}$ tablets $4 \mathrm{mg}$, respectively. All analytical responses obtained were multiplied by 100 (scaling factor of 100) by using a resource of the UVPC software. The spectrophotometric measurements were recorded by using $5 \times 10^{-3} \mathrm{~mol} \mathrm{~L}^{-1}$ sodium hydroxide solution as a blank solution.

\section{Chromatographic conditions}

In order to compare the results of the proposed derivative spectrophotometric method with a reference method, the same product batches were analyzed by a HPLC technique, which was developed and 
validated by our research group. HPLC analyses were carried out using potassium phosphate buffer $(\mathrm{pH} 6.5$, $\left.27.5 \mathrm{mmol} \mathrm{L}^{-1}\right) /$ methanol $(34 / 66, \mathrm{v} / \mathrm{v})$ as mobile phase, flow rate at $1.0 \mathrm{~mL} \mathrm{~min}^{-1}$. The UV detection was carried out at $228 \mathrm{~nm}$ wavelength, and the injection volume was $20 \mu \mathrm{L}$. The column was maintained at controlled room temperature $\left(25^{\circ} \mathrm{C}\right)$.

\section{Preparation of solutions}

\section{Stock and working standard solutions}

Stock standard solution containing $50 \mathrm{mg} \mathrm{L}^{-1}$ of glimepiride was prepared by accurately weighing $12.5 \mathrm{mg}$ of glimepiride reference substance into a $250 \mathrm{~mL}$ volumetric flask and adding $200 \mathrm{~mL}$ of $5 \times 10^{-3} \mathrm{~mol} \mathrm{~L}^{-1}$ sodium hydroxide solution. The flask was sonicated for $30 \mathrm{~min}$ and then filled up to volume with $5 \times 10^{-3} \mathrm{~mol} \mathrm{~L}^{-1}$ $\mathrm{NaOH}$ solution.

Working standard solutions were prepared immediately before use by suitable dilutions of the corresponding stock solutions to appropriate concentration levels by using $5 \times 10^{-3} \mathrm{~mol} \mathrm{~L}^{-1}$ sodium hydroxide solution as diluent. In the HPLC method, the stock standard solution was diluted with mobile phase.

\section{Sample solutions}

Twenty tablets of each dosage form (Amaryl ${ }^{\circledR} 1,2$ and $4 \mathrm{mg}$ ) were used. The tablets were weighed and totally powdered. The mass equivalent to one tablet glimepiride content of each dosage form was weighed into a $50 \mathrm{~mL}$ volumetric flask, $40 \mathrm{~mL}$ of $5 \times 10^{-3} \mathrm{~mol} \mathrm{~L}^{-1}$ sodium hydroxide solution was added and the flask was sonicated for $30 \mathrm{~min}$. The flask was filled up to volume with $5 \times 10^{-3} \mathrm{~mol} \mathrm{~L}^{-1} \mathrm{NaOH}$ solution. Appropriate dilutions were made into the range of calibration curve by using the same solvent. In the HPLC method, samples were diluted with mobile phase.

\section{Stability of the glimepiride in solution}

The stability of the glimepiride stock standard solution in $5 \times 10^{-3} \mathrm{~mol} \mathrm{~L}^{-1}$ sodium hydroxide solution at a concentration of $50 \mathrm{mg} \mathrm{L}^{-1}$ was investigated at different time intervals, by using the experimental conditions.

\section{Method validation}

Method validation was performed following ICH specifications ${ }^{25}$ for selectivity, linearity, accuracy, precision, robustness, detection limit and quantitation limit.

\section{Selectivity}

Selectivity was evaluated by analysis of the secondderivative (D2) spectra of placebo solutions and the glimepiride working standard solution at the concentration of $10 \mathrm{mg} \mathrm{L}^{-1}$. The placebo solutions of Amary ${ }^{\circledR} 1,2$ and $4 \mathrm{mg}$ containing the same composition as the pharmaceutical formulations were prepared for this study. They were treated in the same manner as the commercial samples.

\section{Linearity}

Linearity was evaluated by regression analysis of glimepiride standard solutions at seven concentration points in triplicate ranging from 2 to $40 \mathrm{mg} \mathrm{L}^{-1}$ prepared on three consecutive days $(n=3)$. The values are reported as the mean \pm S.D. of the calibration curves. The data were analyzed at three wavelengths: $256.3,257.5$ and $279.0 \mathrm{~nm}$. Evaluation parameters, such as slope, intercept, correlation coefficient and squares residual sum, were calculated and presented. Moreover, the data were validated by means of the analysis of variance (ANOVA).

\section{Accuracy}

The method accuracy was determined by measuring the reference standard recovery in triplicate at three levels from 80 to $120 \%$ of the method concentration $\left(10 \mathrm{mg} \mathrm{L}^{-1}\right)$, according to ICH recommendations. A standard stock solution containing $50 \mathrm{mg} \mathrm{L}^{-1}$ of glimepiride was prepared in $5 \times 10^{-3} \mathrm{~mol} \mathrm{~L}^{-1} \mathrm{NaOH}$. In volumetric flasks of $25 \mathrm{~mL}$, aliquots of 1.5, 2.5 and $3.5 \mathrm{~mL}$ of this standard solution (concentrations of 3.0, 5.0 and $7.0 \mathrm{mg} \mathrm{L}^{-1}$, respectively) were individually added to $2.5 \mathrm{~mL}$ of sample solutions at $50 \mathrm{mg} \mathrm{L}^{-1}$ (concentration of $5.0 \mathrm{mg} \mathrm{L}^{-1}$ ). The flasks were filled up to volume with $5 \times 10^{-3} \mathrm{~mol} \mathrm{~L}^{-1} \mathrm{NaOH}$ solution. Therefore, final concentrations were 8,10 and $12 \mathrm{mg} \mathrm{L}^{-1}$, which correspond to 80,100 and $120 \%$ of the target concentration, respectively. The mean recoveries, expressed in terms of percent recovery of the pharmaceutical dosage forms (Amary ${ }^{\circledR} 1,2$ and $4 \mathrm{mg}$ ) by the assay and the respective relative standard deviation (R.S.D.), were determined.

\section{Precision}

Precision was evaluated with respect to both repeatability and intermediate precision. Repeatability was evaluated by analyzing glimepiride work standard solutions at the same concentration and during the same day. Intermediate precision was studied by repetition of the assays on two different days by two analysts. Six replicates at a 
concentration of $10 \mathrm{mg} \mathrm{L}^{-1}$ were prepared and assayed. The data were analyzed at three wavelengths: 256.3, 257.5 and $279.0 \mathrm{~nm}$. The percentages of relative standard deviation (R.S.D.) of the analytical responses were calculated.

\section{Robustness}

The robustness of the method was evaluated by analyzing data after checking seven variables according to Youden and Steiner's robustness test. ${ }^{26}$ Glimepiride working standard solutions at the concentration of $10 \mathrm{mg} \mathrm{L}^{-1}$ were used in these experiments. The variables selected were: sodium hydroxide concentration, sodium hydroxide manufacturer, wavelength, sonication time, spectrophotometer cuvette, wavelength interval and scan speed. The variables nominal values were indicated by A, B, $\mathrm{C}, \mathrm{D}, \mathrm{E}, \mathrm{F}$ and $\mathrm{G}$ and their alternative values were indicated by the corresponding lower case letters a, b, c, d, e, f and g. A total of eight experiments were conducted as indicated in Table 1. From these results, the effect of each variable was estimated by obtaining the difference of the averages of the four analyses that have the nominal value (upper case letter) and the four analyses with the alternative value (lower case letter). Considering the standard deviation of the eight results, effect values higher than the criterion s $\sqrt{2}$ (standard deviation multiplied by the square root of two) were considered significant and the method is sensitive to changes in the concerned variable.

\section{Limits of detection and quantification}

The limit of detection (LOD) and the limit of quantification (LOQ) of the methods were obtained from the equations (1) and (2):

$\mathrm{LOD}=3(\mathrm{~S} . \mathrm{D} . / a)$

$$
\mathrm{LOQ}=10(\text { S.D. } / a)
$$

where S.D. is intersection standard deviation and $a$ is the average slope, obtained from calibration curves of the linearity study.

\section{Assay of pharmaceutical products}

The validated second-derivative UV-Vis spectrophotometric method was applied for glimepiride quantitation in tablets (Amaryl® $1 \mathrm{mg}$ tablet; Amaryl® $2 \mathrm{mg}$ tablet and Amaryl ${ }^{\circledR} 4 \mathrm{mg}$ tablet). Moreover, the same product batches were analyzed by a HPLC method. The results were obtained by comparison of the sample spectrophotometric measurements $(n=5)$ with those obtained from glimepiride standard solutions $(n=5)$ at the same concentration levels.

\section{Results and Discussion}

\section{Method development}

The reported methods for the determination of glimepiride are complex, time consuming or require the use of large amounts of organic solvents. In this paper, a non-toxic solvent was chosen in order to obtain an inexpensive, simple and environmentally friendly spectrophotometric method for quantification of glimepiride in tablets. Glimepiride is not soluble in water, acid, base, borate or phosphate buffers. It is partly soluble in methanol, ethanol, acetone and ethylacetate and completely soluble in dimethylformamide..$^{24}$ However, glimepiride is a drug with pH-dependent solubility and, in media at $\mathrm{pH}$ greater than 7 , the solubility of the substance is slightly increased. ${ }^{27}$ Due to $\mathrm{pH}$ effect on drug solubility, sodium hydroxide solutions at different concentrations were tested and $5 \times 10^{-3} \mathrm{~mol} \mathrm{~L}^{-1}$ sodium hydroxide was found to be

Table 1. Variables and their levels according to Youden and Steiner's robustness test ${ }^{26}$

\begin{tabular}{|c|c|c|c|c|c|c|c|c|c|c|}
\hline \multirow{2}{*}{ Selected variable } & \multirow{2}{*}{ Nominal conditions } & \multirow{2}{*}{ Alternative conditions } & \multicolumn{8}{|c|}{ Experimental condition $^{\mathrm{a}}$} \\
\hline & & & 1 & 2 & 3 & 4 & 5 & 6 & 7 & 8 \\
\hline $\mathrm{NaOH}$ concentration & $5 \times 10^{-3} \mathrm{~mol} \mathrm{~L}^{-1}(\mathrm{~A})$ & $4 \times 10^{-3} \mathrm{~mol} \mathrm{~L}^{-1}$ (a) & A & A & A & A & a & a & a & $\mathrm{a}$ \\
\hline $\mathrm{NaOH}$ manufacturer & Impex (B) & Dinamic (b) & $\mathrm{B}$ & B & $\mathrm{b}$ & $\mathrm{b}$ & B & B & $\mathrm{b}$ & $\mathrm{b}$ \\
\hline Wavelength & Optimum (C) & Increase of $2 \mathrm{~nm}(\mathrm{c})$ & $\mathrm{C}$ & $\mathrm{c}$ & $\mathrm{C}$ & $\mathrm{c}$ & $\mathrm{C}$ & $\mathrm{c}$ & $\mathrm{C}$ & $\mathrm{c}$ \\
\hline Sonication time & $30 \min (\mathrm{D})$ & $20 \min (d)$ & $\mathrm{D}$ & $\mathrm{D}$ & $\mathrm{d}$ & $\mathrm{d}$ & $\mathrm{d}$ & $\mathrm{d}$ & $\mathrm{D}$ & $\mathrm{D}$ \\
\hline Cuvette & $1 \mathrm{~cm}(\mathrm{E})$ & $2 \mathrm{~cm}(\mathrm{e})$ & $\mathrm{E}$ & $\mathrm{e}$ & $\mathrm{E}$ & $\mathrm{e}$ & $\mathrm{e}$ & $\mathrm{E}$ & $\mathrm{e}$ & $\mathrm{E}$ \\
\hline$\Delta \lambda$ & $8 \mathrm{~nm}(\mathrm{~F})$ & $4 \mathrm{~nm}(\mathrm{f})$ & $\mathrm{F}$ & $\mathrm{f}$ & $\mathrm{f}$ & $\mathrm{F}$ & $\mathrm{F}$ & $\mathrm{f}$ & $\mathrm{f}$ & $\mathrm{F}$ \\
\hline Scan speed & Fast (G) & Slow $(g)$ & $\mathrm{G}$ & $\mathrm{g}$ & $\mathrm{g}$ & $\mathrm{G}$ & $\mathrm{g}$ & $\mathrm{G}$ & $\mathrm{G}$ & $\mathrm{g}$ \\
\hline Observed results & & & $\mathrm{s}$ & $\mathrm{t}$ & $\mathrm{u}$ & $\mathrm{v}$ & $\mathrm{w}$ & $\mathrm{x}$ & $\mathrm{y}$ & $\mathrm{z}$ \\
\hline
\end{tabular}

${ }^{a}$ Upper case letters represent nominal conditions and lower case letters represent alternative conditions. 
an adequate solvent for dissolving glimepiride, avoiding the use of an organic solvent.

Zero-order UV-Vis spectrum of glimepiride in $5 \times 10^{-3} \mathrm{~mol} \mathrm{~L}^{-1}$ sodium hydroxide showed maximum drug absorption wavelength above $230 \mathrm{~nm}$. However, significant interference from the tablet excipients was verified in the region of glimepiride absorption spectrum, which precludes the analytical use of zero-order spectrophotometry (Figure 2). For this reason, the second-order derivative spectrophotometric method (D2) was considered to be ideal for solving the overlapping of excipients absorption over glimepiride signal. As observed in Figure 3, the zerocrossing for tablets 1,2 and $4 \mathrm{mg}$ placebo solutions appears at $279.0,257.5$ and $256.3 \mathrm{~nm}$, respectively. Therefore, these values were selected as optimum to determine glimepiride in the presence of the pharmaceutical excipients, which are contained in Amary ${ }^{\circledR}$ tablets. The first, third, and fourth derivatives were discarded because they showed insufficient selectivity and did not present analytical advantages.

To verify the optimum $\Delta \lambda$ for obtaining secondderivative spectra various values of $\Delta \lambda$ were tested and $\Delta \lambda=8 \mathrm{~nm}$ was chosen as the most appropriate in order to give an adequate signal-to-noise ratio. Increasing $\Delta \lambda$,

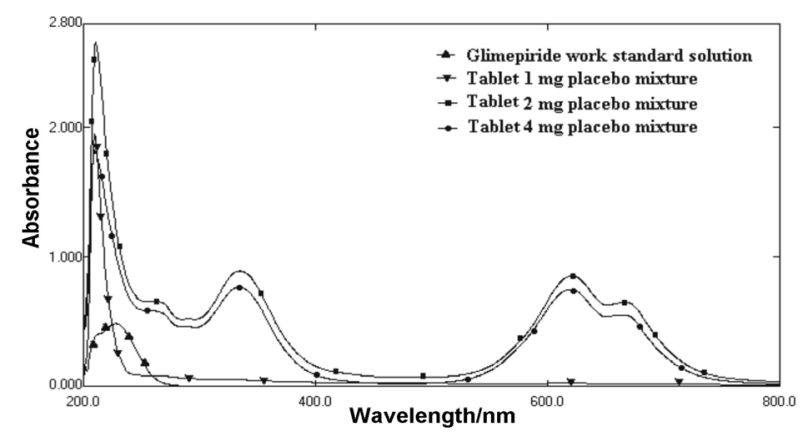

Figure 2. Zero-order absorption spectra of 1, 2 and $4 \mathrm{mg}$ placebo solutions and glimepiride work standard solution at $10 \mathrm{mg} \mathrm{L}^{-1}$ in $5 \times 10^{-3} \mathrm{~mol} \mathrm{~L}^{-1}$ sodium hydroxide.

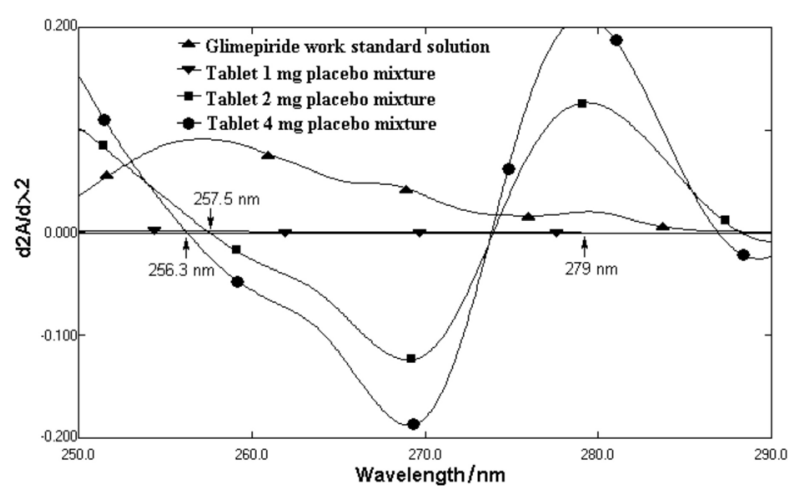

Figure 3. Second-derivative absorption spectra of 1,2 and $4 \mathrm{mg}$ placebo solutions and glimepiride work standard solution at $10 \mathrm{mg} \mathrm{L}^{-1}$ in $5 \times 10^{-3} \mathrm{~mol} \mathrm{~L}^{-1}$ sodium hydroxide.

the signal-to-noise ratio improves and the fluctuation in a derivative spectrum decreases. However, if the value of $\Delta \lambda$ is too large, the spectral intensity signal of secondderivative deteriorates.

\section{Stability of the glimepiride in solution}

The results from stability study indicated that the glimepiride stock standard solution was stable at room temperature for at least $6 \mathrm{~h}$ (Table 2).

\section{Method validation}

After identifying derivative order and optimum wavelength for each dosage form $\left(279.0 \mathrm{~nm}\right.$ for Amaryl ${ }^{\circledR}$ Tablets $1 \mathrm{mg}, 257.5 \mathrm{~nm}$ for Amaryl ${ }^{\circledR}$ Tablets $2 \mathrm{mg}$ and 256.3 for Amaryl ${ }^{\circledR}$ Tablets $4 \mathrm{mg}$ ), the analytical method was validated according to $\mathrm{ICH}$ recommendations. ${ }^{25}$

\section{Selectivity}

The second-derivative spectra analyses show that formulation excipients of the pharmaceutical tablet products

Table 2. Stability of glimepiride stock standard solution at concentration of $50 \mathrm{mg} \mathrm{L}^{-1}$ in $5 \times 10^{-3} \mathrm{~mol} \mathrm{~L}^{-1}$ sodium hydroxide solution

\begin{tabular}{lccccccccc}
\hline & & $0 \mathrm{~h}$ & $1 \mathrm{~h}$ & $2 \mathrm{~h}$ & $3 \mathrm{~h}$ & $4 \mathrm{~h}$ & $5 \mathrm{~h}$ & $6 \mathrm{~h}$ \\
\hline \multirow{3}{*}{ Responses at 256.3 nm } & $1(\mathrm{~d} 2 \mathrm{~A} / \mathrm{d} \lambda 2)$ & 0.4276 & 0.4304 & 0.4243 & 0.4244 & 0.4255 & 0.4249 & 0.4242 \\
& $2(\mathrm{~d} 2 \mathrm{~A} / \mathrm{d} \lambda 2)$ & 0.4275 & 0.4252 & 0.4259 & 0.4244 & 0.4252 & 0.4200 & 0.4235 \\
& $3(\mathrm{~d} 2 \mathrm{~A} / \mathrm{d} \lambda 2)$ & 0.4270 & 0.4280 & 0.4275 & 0.4086 & 0.4200 & 0.4194 & 0.4249 \\
& $1(\mathrm{~d} 2 \mathrm{~A} / \mathrm{d} \lambda 2)$ & 0.4390 & 0.4426 & 0.4391 & 0.4376 & 0.4378 & 0.4373 & 0.4369 \\
\multirow{2}{*}{ Responses at 257.5 nm } & $2(\mathrm{~d} 2 \mathrm{~A} / \mathrm{d} \lambda 2)$ & 0.4397 & 0.4374 & 0.4393 & 0.4376 & 0.4383 & 0.4326 & 0.4361 \\
& $3(\mathrm{~d} 2 \mathrm{~A} / \mathrm{d} \lambda 2)$ & 0.4395 & 0.4406 & 0.4394 & 0.4201 & 0.4321 & 0.4320 & 0.4369 \\
& & & & & & & & \\
Responses at 279.0 nm & $1(\mathrm{~d} 2 \mathrm{~A} / \mathrm{d} \lambda 2)$ & 0.1003 & 0.1011 & 0.1006 & 0.1000 & 0.1007 & 0.1005 & 0.1005 \\
& $2(\mathrm{~d} 2 \mathrm{~A} / \mathrm{d} \lambda 2)$ & 0.1007 & 0.1001 & 0.1004 & 0.1000 & 0.1006 & 0.0998 & 0.1002 \\
& $3(\mathrm{~d} 2 \mathrm{~A} / \mathrm{d} \lambda 2)$ & 0.1008 & 0.1015 & 0.1002 & 0.0959 & 0.0993 & 0.0993 & 0.1003 \\
\hline
\end{tabular}


Table 3. Linearity parameters for the determination of glimepiride ${ }^{a}$

\begin{tabular}{lccc}
\hline Parameter & $256.3 \mathrm{~nm}$ & $257.5 \mathrm{~nm}$ & $279.0 \mathrm{~nm}$ \\
\hline Linearity range $\left(\mathrm{mg} \mathrm{L}^{-1}\right)$ & $2-40$ & $2-40$ & $2-40$ \\
Slope & $0.0086 \pm 0.00026$ & $0.0087 \pm 0.00035$ & $0.0020 \pm 0.00089$ \\
Intercept & $-0.0011 \pm 0.00237$ & $-0.0008 \pm 0.00291$ & $-0.0002 \pm 0.00006$ \\
Correlation coefficient $(r)$ & $0.99989 \pm 0.00026$ & $0.99991 \pm 0.00028$ & $0.99993 \pm 0.00024$ \\
Residual sum of squares & 0.000300 & 0.000545 & 0.000011 \\
\hline
\end{tabular}

${ }^{a}$ Values are reported as mean \pm S.D. of three calibration curves generated on three consecutive days $(n=3)$.

Amaryl $^{\circledast} 1,2$ and $4 \mathrm{mg}$ did not interfere significantly in the second-derivative spectrophotometric method (Figure 3). The obtained values of the analytical responses $(\mathrm{d} 2 \mathrm{~A} / \mathrm{d} \lambda 2)$ for placebo mixtures were: 0.0000 at $279.0 \mathrm{~nm}$ for tablet $1 \mathrm{mg}$ placebo mixture, 0.0004 at $257.5 \mathrm{~nm}$ for tablet $2 \mathrm{mg}$ placebo mixture and -0.0005 at $256.3 \mathrm{~nm}$ for tablet $4 \mathrm{mg}$ placebo mixture. These values correspond to $0.0,0.43$ and $-0.55 \%$ of the signals at $279.0,257.5$ and $256.3 \mathrm{~nm}$, respectively.

\section{Linearity}

The analytical curves, generated on three consecutive days $(n=3)$ by plotting the mean amplitude values of second-derivative spectra at 279.0, 257.5 and $256.3 \mathrm{~nm}$ against concentration yielded correlation coefficients greater than 0.999 (Table 3). Additionally, the data were validated by means of analysis of variance (Table 4), which showed significant linear regression (Fcalculated $>$ Fcritical, $\mathrm{P}=5 \%$ ) and no significant lack of fit (Fcalculated $<$ Fcritical, $\mathrm{P}=5 \%$ ). The $\mathrm{Y}$ intercept were not significantly different from zero.

Table 4. Summary of ANOVA for the evaluation of linearity

\begin{tabular}{lccc}
\hline Wavelength & Source & $\begin{array}{c}\text { Calculated } \\
F \text { value }\end{array}$ & Critical $F$ value \\
\hline $256.3 \mathrm{~nm}$ & Regression & 15848.64 & 4.38 \\
& Lack of fit & 0.66 & 2.96 \\
$257.5 \mathrm{~nm}$ & Regression & 9001.46 & 4.38 \\
& Lack of fit & 0.27 & 2.96 \\
$279.0 \mathrm{~nm}$ & Regression & 24573.74 & 4.38 \\
& Lack of fit & 0.58 & 2.96 \\
\hline
\end{tabular}

\section{Accuracy}

The accuracy of the method was confirmed by determining the average recoveries from the samples by applying the standard addition method. As shown in Table 5, the mean percentage recoveries of products Amaryl ${ }^{\circledR} 1,2$ and $4 \mathrm{mg}$ were in accordance with fixed limits of 98.0 up to $102.0 \%$, indicating the suitability of the developed method in quantifying the concentration of glimepiride in pharmaceutical tablets.

Table 5. Method accuracy results for glimepiride tablets

\begin{tabular}{|c|c|c|c|c|c|}
\hline \multirow{2}{*}{$\begin{array}{l}\text { Samples at } \\
5 \mathrm{mg} \mathrm{L}^{-1}\end{array}$} & \multicolumn{2}{|c|}{$\begin{array}{l}\text { Reference standard } \\
\text { concentration }\left(\mathrm{mg} \mathrm{L}^{-1}\right)\end{array}$} & \multirow{2}{*}{$\begin{array}{l}\text { R.S.D. } \\
(\%) \mathrm{n}=3\end{array}$} & \multirow{2}{*}{$\begin{array}{c}\text { Recovery } \\
(\%)\end{array}$} & \multirow{2}{*}{$\begin{array}{c}\text { Mean } \\
\text { recovery } \\
(\%)\end{array}$} \\
\hline & Added & Found & & & \\
\hline \multirow{3}{*}{$\begin{array}{l}\text { Amaryl }{ }^{\circledR} 1 \mathrm{mg} \\
(279.0 \mathrm{~nm})\end{array}$} & 3.0 & 2.9 & 2.69 & 97.98 & \multirow{3}{*}{99.43} \\
\hline & 5.0 & 5.1 & 3.04 & 101.28 & \\
\hline & 7.0 & 6.9 & 4.59 & 99.04 & \\
\hline \multirow{3}{*}{$\begin{array}{l}\text { Amaryl }{ }^{\circledR} 2 \mathrm{mg} \\
(257.5 \mathrm{~nm})\end{array}$} & 3.0 & 3.0 & 0.34 & 101.10 & \multirow{3}{*}{99.77} \\
\hline & 5.0 & 5.0 & 0.60 & 100.66 & \\
\hline & 7.0 & 6.8 & 0.43 & 97.54 & \\
\hline \multirow{3}{*}{$\begin{array}{l}\text { Amaryl }^{\circledR} 4 \mathrm{mg} \\
(256.3 \mathrm{~nm})\end{array}$} & 3.0 & 2.9 & 2.02 & 97.70 & \multirow{3}{*}{98.09} \\
\hline & 5.0 & 5.0 & 0.32 & 99.18 & \\
\hline & 7.0 & 6.8 & 0.38 & 97.38 & \\
\hline
\end{tabular}

\section{Precision}

Repeatability (intra-day precision) of the analytical method was found to be reliable based on \%R.S.D. $(<2 \%)$. Intermediate precision (inter-day precision) was demonstrated on different days by two analysts. The $\%$ R.S.D. values were less than $2 \%$, confirming that the method is sufficiently precise (Table 6).

\section{Robustness}

The results obtained in Youden and Steiner's robustness test $^{26}$ are shown in Table 7. The effect of each variable, standard deviation of the eight results and the criterion s $\sqrt{2}$ were calculated and used to evaluate the results. Effect values higher than the criterion $\mathrm{s} \sqrt{2}$ were considered significant and the method is sensitive to changes in the concerned variable. The results indicate that a variation of $2 \mathrm{~nm}$ in wavelength is the only variable that needs to be controlled for quantification of Amary $1^{\circledR} 1 \mathrm{mg}$ tablet. Therefore, the method is fairly robust with regard to the parameters sodium hydroxide concentration, sodium hydroxide manufacturer, 
Table 6. Method precision results for glimepiride tablets

\begin{tabular}{|c|c|c|c|c|c|c|c|c|}
\hline \multirow{2}{*}{ Wavelength } & \multirow{2}{*}{ Level } & \multicolumn{6}{|c|}{ Analytical responses $(\mathrm{d} 2 \mathrm{~A} / \mathrm{d} \lambda 2)$} & \multirow{2}{*}{ R.S.D (\%) } \\
\hline & & 1 & 2 & 3 & 4 & 5 & 6 & \\
\hline \multirow{3}{*}{$279.0 \mathrm{~nm}$} & Repeatability & 0.0211 & 0.0214 & 0.0217 & 0.0213 & 0.0218 & 0.0211 & $1.39(n=6)$ \\
\hline & & 0.0211 & 0.0214 & 0.0217 & 0.0213 & 0.0218 & 0.0211 & \multirow{2}{*}{$1.74(n=12)$} \\
\hline & intermediated precision & 0.0211 & 0.0212 & 0.0207 & 0.0209 & 0.0207 & 0.0207 & \\
\hline \multirow{3}{*}{$257.5 \mathrm{~nm}$} & Repeatability & 0.0944 & 0.0933 & 0.0930 & 0.0923 & 0.0928 & 0.0913 & $1.11(n=6)$ \\
\hline & Intermediated precis & 0.0944 & 0.0933 & 0.0930 & 0.0923 & 0.0928 & 0.0913 & \multirow{2}{*}{$1.02(n=12)$} \\
\hline & mitermedrated piecision & 0.0943 & 0.0927 & 0.0915 & 0.0921 & 0.0927 & 0.0928 & \\
\hline \multirow{3}{*}{$256.3 \mathrm{~nm}$} & Repeatability & 0.0917 & 0.0906 & 0.0903 & 0.0897 & 0.0903 & 0.0890 & $1.00(n=6)$ \\
\hline & & 0.0917 & 0.0906 & 0.0903 & 0.0897 & 0.0903 & 0.0890 & \multirow{2}{*}{$1.14(\mathrm{n}=12)$} \\
\hline & Intermediated precision & 0.0929 & 0.0914 & 0.0903 & 0.0909 & 0.0915 & 0.0915 & \\
\hline
\end{tabular}

Table 7. Robustness test results

\section{Effects}

\begin{tabular}{lccc} 
Factor & $\begin{array}{c}\text { Amaryl } \\
(279.0 \mathrm{~nm})\end{array}$ & $\begin{array}{c}\text { Amary } 1^{\circledR} 2 \mathrm{mg} \\
(257.5 \mathrm{~nm})\end{array}$ & $\begin{array}{c}\text { Amaryl }^{\circledR} 4 \mathrm{mg} \\
(256.3 \mathrm{~nm})\end{array}$ \\
\hline $\mathrm{NaOH}$ concentration & 0.0009 & -0.0012 & -0.0028 \\
$\mathrm{NaOH}$ manufacturer & -0.0059 & 0.0115 & 0.0105 \\
Wavelength & $0.0101^{\mathrm{a}}$ & -0.0065 & -0.0115 \\
Sonication time & 0.0009 & 0.0041 & 0.0023 \\
Cuvette & -0.0011 & -0.0029 & -0.0011 \\
Wavelength interval & -0.0027 & -0.0151 & -0.0042 \\
Scan speed & -0.0015 & 0.0005 & 0.0009 \\
s $\sqrt{2}$ & 0.0092 & 0.0156 & 0.0125 \\
\hline
\end{tabular}

${ }^{a}$ Effect value higher than the criterion $\mathrm{s} \sqrt{ } 2$.

sonication time, spectrophotometer cuvette, wavelength interval and scan speed.

\section{Limits of detection and quantification}

LOD and LOQ values were found to be respectively 1.311 and $4.371 \mathrm{mg} \mathrm{L}^{-1}$ for Amaryl ${ }^{\circledR}$ tablets $1 \mathrm{mg}$ (279.0 nm); 1.000 and $3.332 \mathrm{mg} \mathrm{L}^{-1}$ for Amaryl ${ }^{\circledR}$ tablets $2 \mathrm{mg}(257.5 \mathrm{~nm})$; and 0.826 and $2.755 \mathrm{mg} \mathrm{L}^{-1}$ for Amaryl ${ }^{\circledR}$ tablets $4 \mathrm{mg}(256.3 \mathrm{~nm})$. These results demonstrated that the analyses were being performed in a region above the quantitation limit value.

\section{Assay of pharmaceutical products}

The validated method was applied for determination of glimepiride in tablets. Five samples from each product (Amaryl ${ }^{\circledR} 1 \mathrm{mg}$ tablet; Amaryl ${ }^{\circ} 2 \mathrm{mg}$ tablet and Amaryl ${ }^{\circledR}$ $4 \mathrm{mg}$ tablet) were analyzed. Moreover, the same product batches were analyzed by a HPLC technique. The results, expressed as percentage drug related to label claim, are shown in Table 8. As it can be seen, the results for the drugs assayed using the proposed spectrophotometric method were in good agreement with the HPLC technique.

\section{Conclusions}

In this work, an analytical derivative UV spectrophotometric method was developed for quantitative determination of glimepiride in tablets. Its advantages over other existing methods are its simplicity, fastness and low-cost conditions. Moreover, it does not use polluting reagents.

All validation parameters were found to be highly satisfactory, indicating linearity, selectivity, precision,

Table 8. Assay of glimepiride in pharmaceutical capsule samples A, B and C

\begin{tabular}{|c|c|c|c|c|c|}
\hline Method & & Standard & $\begin{array}{c}\text { Amaryl® } 1 \mathrm{mg} \\
(279.0 \mathrm{~nm})\end{array}$ & $\begin{array}{c}\text { Amaryl }{ }^{\circledR} 2 \mathrm{mg} \\
(257.5 \mathrm{~nm})\end{array}$ & $\begin{array}{c}\text { Amaryl® } 4 \mathrm{mg} \\
(256.3 \mathrm{~nm})\end{array}$ \\
\hline \multirow{3}{*}{$\begin{array}{l}\text { Derivative } \\
\text { spectrophotometry }\end{array}$} & Glimepiride (\%) & 100.12 & 100.21 & 100.34 & 103.93 \\
\hline & Glimepiride (mg) & --- & 1.00 & 2.01 & 4.16 \\
\hline & R.S.D. (\%) & $1.03(\mathrm{n}=5)$ & $2.19(\mathrm{n}=5)$ & $1.38(\mathrm{n}=5)$ & $1.02(\mathrm{n}=5)$ \\
\hline \multirow{3}{*}{ HPLC } & Glimepiride (\%) & 100.12 & 100.86 & 101.49 & 100.66 \\
\hline & Glimepiride (mg) & --- & 1.01 & 2.03 & 4.03 \\
\hline & R.S.D. (\%) & $0.59(n=5)$ & $1.17(\mathrm{n}=5)$ & $1.91(\mathrm{n}=5)$ & $1.68(n=5)$ \\
\hline
\end{tabular}


accuracy, robustness and adequate detection and quantification limits. The method, therefore, can be easily applied in routine quality control laboratories.

\section{Acknowledgments}

The authors are grateful to FAPESP (São Paulo, Brazil), CNPq (Brasília, Brazil) and PADC/FCF/UNESP (Araraquara, Brazil) for research fellowships.

\section{References}

1. European Pharmacopoeia, $6^{\text {th }}$ ed., Council of Europe: Strasbourg, France, 2008.

2. Roßkamp, R.; Wernicke-Panten, K.; Draeger, E.; Diabetes Res. Clin. Pract. 1996, 31, S33.

3. Draeger, K. E.; Wernicke-Panten, K.; Lomp, H. J.; Schüler, E.; Roßkamp, R.; Horm. Metab. Res. 1996, 28, 419.

4. FDA Guidance for Industry: Statistical Approaches to Establishing Bioequivalence, US Department of Health and Human Services, Food and Drug Administration, Centre for Drug Evaluation and Research (CDER), 2010, http:// www.accessdata.fda.gov/scripts/cder/drugsatfda/index. cfm?fuseaction=Search.Label_ApprovalHistory, accessed in June, 2010.

5. Lehr, K. H.; Damm, P.; J. Chromatogr. 1990, 26, 497.

6. Song, Y. K.; Maeng, J. E.; Hwang, H. R.; Park, J. S.; Kim, B. C.; Kim, J. K.; Kim, C. K.; J. Chromatogr., B 2004, 810, 143.

7. Núñez, M.; Ferguson, J. E.; Machacek, D.; Jacob, G.; Oda, R. P.; Lawson, G. M.; Landers, J. P.; Anal. Chem. 1995, 67, 3668.

8. Maurer, H. H.; Kratzsch, C.; Kraemer, T.; Peters, F. T.; Weber, A. A.; J. Chromatogr., B 2002, 773, 63.

9. Kim, H.; Chang, K. Y.; Park, C. H.; Jang, M. S.; Lee, J. A.; Lee, H. J.; Lee, K. R.; Chromatographia 2004, 60, 93.

10. Salem, I. I.; Idrees, J.; Al Tamimi, J. I.; J. Chromatogr., B 2004, 799, 103.

11. Pistos, C.; Koutsopoulou, M.; Panderi, I.; Biomed. Chromatogr. 2005, 19, 394
12. Yüzüak, N.; Özden, T.; Eren, S.; Özilhan, S.; Chromatographia 2007, 66, S165.

13. Chakradhar, L.; Kallem, R.; Karthik, A.; Tripura Sundari, B.; Ramesh, S.; Mullangi, R.; Srinivas, N. R.; Biomed. Chromatogr. 2008, 22, 58 .

14. Kovař̀ková, P.; Klimeš, J.; Dohnal, J.; Tisovská, L.; J. Pharm. Biomed. Anal. 2004, 36, 205.

15. Khan, M. A.; Sinha, S.; Vartak, S.; Bhartiya, A.; Kumar, S.; J. Pharm. Biomed. Anal. 2005, 39, 928.

16. Kolte, B. L.; Raut, B. B.; Deo, A. A.; Bagool, M. A.; Shinde, D. B.; J. Sep. Sci. 2005, 28, 2076.

17. Pathare, D. B.; Jadhav, A. S.; Shingare, M. S.; Chromatographia 2007, 66, 639.

18. Pawar, S. P.; Meshram, G. A.; Phadke, M. U.; Chromatographia 2008, 68, 1063.

19. Khan, I. U.; Aslam, F.; Ashfaq, M.; Asghar, M. N.; J. Anal. Chem. 2009, 64, 171.

20. Jain, D.; Jain, S.; Jain, D.; Amin, M.; J. Chromatogr. Sci. 2008, 46, 501.

21. Bansal, G.; Singh, M.; Jindal, K. C.; Singh, S.; J. Pharm. Biomed. Anal. 2008, 48, 788.

22. Мa, H. L.; Хu, M. T.; Qu, P.; Ma, X. H.; Yаохие Хиеbao (Acta Pharm. Sinica) 2005, 40, 750.

23. Patel, J. R.; Suhagia, B. N.; Patel, M. M.; Asian J. Chem. 2006, $18,2873$.

24. Altinöz, S.; Tekeli, D.; J. Pharm. Biomed. Anal. 2001, 24, 507.

25. ICH Q2(R1), International Conference on Harmonization, Validation of analytical procedures: Text and methodology, 2005.

26. Youden, W. J.; Steiner, E. H.; Statistical Manual of the $A O A C, 48^{\text {th }}$ ed., Association of Official Analytical Chemists: Arlington, VA, 1975.

27. Frick, A.; Möller, H.; Wirbitzki, E.; Eur. J. Pharm. Biopharm. 1998, 46, 305.

Submitted: June 16, 2010

Published online: September 30, 2010

FAPESP has sponsored the publication of this article. 